\title{
Attitudes of a sample of English, Maltese and German teachers towards media education
}

\author{
M.A. Lauri ${ }^{\mathrm{a} *}$, J. Borg ${ }^{\mathrm{b}}, \mathrm{T}$. Günnel ${ }^{\mathrm{c}}$ and R. Gillum \\ ${ }^{a}$ Department of Psychology, University of Malta, Tal-Qroqq, Malta; ${ }^{b}$ Centre for \\ Communication Technology, University of Malta, Tal-Qroqq, Malta; ${ }^{c}$ Pädagogische \\ Hochschule, Freiburg Im Breisgau, Germany
}

\begin{abstract}
Media education forms part of the National Minimum Curriculum of England, Malta and Germany. Teacher training courses differ greatly in how teachers are prepared to teach media education. In this paper we shall investigate the attitudes of a sample of teachers trained in England, Malta and in Germany towards their perceived importance of media education and the teachers' preparedness to teach the subject. This preliminary study had a sample of 132 participants, 33 teachers from England, 47 from Germany and 52 teachers from Malta. The tool used to collect data was an online questionnaire. The results show that teachers taking part in this study were not given enough training, or any training at all to be able to teach media education with the result that they do not feel sufficiently prepared to teach the subject. It is suggested by the authors that media education becomes a compulsory component of the initial teacher training courses as well as advanced training for teachers.
\end{abstract}

Keywords: media education; initial teacher training; attitudes

\section{Introduction}

Educationalists and policy-makers in many countries have issued several directives about the importance of media education. Moreover many researchers have argued that due to the influence of media in children's lives, media education is of crucial importance to children's development (see Harris 2004; Van Evra 1998; von Feilitzen and Carlsson 2004). During the last 25 years a large number of official documents issued by different authorities and organisations considered the role of teachers as pivotal in the process of media education. Three important examples are the Grunwald Declaration (UNESCO 1982), Recommendation 1466 adopted by the Parliamentary Assembly of the Council of Europe in 2000, and the Audiovisual Media Services Directive of the European Union (AVMS Directive 2007). The Grunwald Declaration (UNESCO 1982) discusses the role of teachers in helping students become critical evaluators of media structures and media content. Paragraph 10 of the Council of Europe declaration states that qualified teachers and teaching materials are the basic elements in media education and therefore constant attention should be paid to both initial and continuing teacher education. The AVMS directive (2007) recommends the continuing education of teachers in media studies so that they will be able to fulfil their roles as media educators.

This paper looks at this important role of teachers in media education by studying the attitudes of teachers in three different European countries - England, Malta and

\footnotetext{
*Corresponding author. Email: mary-anne.lauri@um.edu.mt
} 
Germany, where media education has been part of the education system for more than two decades. It also gives a brief account of the history of media education and looks at the current practices of teaching media education in these three countries. Although they embrace the same objectives of media education, these countries have different ways of integrating media education into the mainstream curriculum. This preliminary study investigates the attitudes of a sample of teachers toward the training they received to teach media education, as well as their attitudes about whether and how it should be taught in schools. This is done with the aim of sharing this information with other teachers who wish to know how media education is carried out in these three countries as well as give feedback to educational authorities and policy-makers regarding the attitudes of a sample of teachers on media education.

\section{History of media education}

In the UK, media education began as early as the 1930s through what is considered the first paradigm of media education, known as the inoculatory approach. The mass media at the time were perceived to have a very strong and generally bad effect on audiences (Williams 2003). Media education was consequently deemed necessary to ensure that students developed a discriminatory attitude towards the popular media. Leavis and Thompson (1933) were proponents of this theory and stressed the importance of an informed and discriminating, highly-trained intellectual elite who would help preserve the cultural continuity of English life and literature. Thus the popular media were not seen as something that merited to be studied in themselves, but as something that one needed to learn about mainly in order to conserve social balance.

Similarly, in Germany, the so-called 'normative approaches' of media education characterised also as 'protective pedagogy' concentrated on establishing standards and on developing preventive measures to protect recipients from ethically or morally objectionable media content (Gerbner 1981; Glogauer 1991). This approach is based on the sceptical view of media prevalent especially in the post-war period by many educators wishing to distance themselves from the manipulative power of media under Hitler's regime (Hüther 2004). Even today, there is still some scepticism towards the influences of the media. This can be seen for example in discussions on whether depictions of violence in film and television tend to reduce young people's inhibitions and encourage imitation, and on whether such media productions should be prohibited (see Pfeiffer et al. 2007; Spitzer 2005).

In the 1960s this paradigm shifted to the one of popular arts. Masterman (1988), in his review of the development of media education in Europe writes that this movement sought to encourage discrimination within the media and not discrimination against the media. Teachers no longer tried to convince people that media was destructive or that society needed to be protected from the media but stressed the importance of the need to be able to talk critically about, rather than against, the media. As a result media education began to focus more on different types of media, especially television, radio, newspapers and magazines. Students began to experiment with media production as a means of understanding it. In the context of the so-called 'alternative' political and social movements such as campaigning against nuclear power stations, cheap housing space, disarmament and, more generally, campaigning for civic participation, media education encouraged critical and autonomous media practice as an 
alternative to established media (Enzensberger 1970; Günnel 2001). Kleinsteuber (1991), argues that as a result of the above, the 'so-called small scale electronic media - local radio and television stations' (Jankowski 2002, 4) arose in many European countries.

The popular arts movement like the aesthetic approach put forward by Minkkinem (1978) gave importance to the proper use of different media languages. The model used in Malta since the beginning of the 1980s reflected both the aesthetic as well as the communicative approach and aimed to help students understand audiovisual messages while simultaneously training them to express themselves audiovisually. This model aimed to help students change from passive media consumers to empowered media partners. The 1980s saw in England the rise of another paradigm known as the representational paradigm, where education addressed issues of ideology: the power and politics of representation. Masterman in his seminal work Teaching the media, made an attempt to summarise the 50-year history of media education, most of which had been dominated by more traditional Leavisite approaches (Masterman 1985). He demonstrated the lines of continuity between, and the problems shared by, the approaches of Leavis and Thompson (1933) and Hall and Whannel (1964) and stressed their importance and significance within their eras. He then shifted the focus of media education to the consumption of images and representations. Thus media education in the classroom began to focus on understanding the ways in which the media represent reality, the techniques they employ, and the ideologies embedded within their respective representations.

Action-oriented media pedagogy (AOMP) in its theoretical, methodological and practical dimensions (Günnel 2006; Schorb 1995; Baacke 1997; Schell 1999) can be regarded as another paradigm. In Germany it was developed as a separate discipline within media education in the context of the debate over an 'emancipatory' approach in education theory. By the 1980s, it was generally recognised as an accepted approach. According to media theorists Jürgen Hüther and Bernd Schorb, AOMP was concerned with 'democratising the structure of communication... as well as in using media as a means toward behavioral change and development of perceptive abilities through active and self-directed handling of media' (Hüther, Schorb, and BrehmKlotz 1997, 244). According to Baacke (1997) AOMP include key concepts such as communication competence, media competence, self-responsibility and competent action.

\section{Specialist subject vs. interdisciplinary debate}

Whether media education in schools should be taught as a specialist subject or be integrated with other subjects is a continuing debate. In the late 1980s, Masterman (1988) outlined three possibilities for the inclusion of media education:

(a) as a specialist area of study in its own right;

(b) as an integrated part of more traditional disciplines;

(c) as a distinct and separable 'theme' within a particular subject area. (Masterman 1988, 21)

Masterman's position is that media education should be part of the teaching of all subjects. 
Other researchers like Minkkinen (1978) argue that teaching media education as part of other subjects can mean that not all aspects of media education are covered and that 'ideally, mass media education should be a subject on its own' (126). The debate is as alive today as it was 20 years ago years ago (Buckingham 2003). Frau-Meigs (2006) points out that in the English-speaking world, media education is now fairly well established as a specialist subject in secondary schools. Experience shows that over the past 20 years these specialist media studies courses have experienced a steady growth in student numbers as well as a phenomenal expansion of media courses in higher education (Frau-Meigs 2006). But these are optional courses and not a core part of teaching consequently these courses 'have always remained vulnerable to cuts; and there has never been anything resembling a "career structure" for specialist media teachers' (Frau-Meigs 2006, 12). Frau-Meigs writes that when media education is part of other subjects it may be seen to play an important role in the curriculum but warns that 'this might reduce media education to an instrumental or "servicing role" and that an issue that is every teachers' responsibility can quickly become nobody's responsibility' (13).

\section{Media in the curriculum}

\section{England}

In the 1980s and 1990s teachers realised the importance of having media education on the school curriculum (Dickson 1994). By the end of the 1980s, media education had been squeezed into different parts of the National Curriculum, and by the 1990s media education began to be seen as a 'fundamental educational entitlement for all' (Buckingham 1993, 3). This was justified, as knowledge of the way in which the media work was seen as a 'theoretical basis for learning about contemporary culture', and a 'central aspect of what it means to be literate in contemporary societies' (Buckingham 1993, 3). Although distinct qualifications in media studies became available as early as the 1970s, its place in the National Curriculum remained ambiguous even in the 1980s and 1990s.

Presently, both at primary and secondary levels, media education is only compulsory as part of English/literacy. Due to this, media education is often seen by teachers as 'a theme which would be taught through core and foundation subjects' (Bowker 1991, 68). In Key Stages 1 and 2 (between 4 and 11 years) its presence in the National Curriculum is limited to a reference to 'non-fiction and non-literary texts'. At secondary level, this is expanded to include 'printed and ICT-based texts' and 'media and moving-image texts'. However, although in many schools students engage in topics such as film studies and film production, it is not uncommon to find English teachers establishing priorities that privilege the print medium. This is also the case with the examinations for English at SATs and GCSE levels. Indeed, without exception, all examination boards (AQA, WJEC, Edexcel, OCR) for GCSE English have placed the requirement 'responses to media' as part of the final written paper, as opposed to the coursework option, which could have for example resulted in practical work such as film production. This again results in a dependence on print-based texts.

Although the mention of media education within the National Curriculum for England is minimal, at GCSE level it has become popular as an optional subject. Hart and Hicks (2002) stated that in the 1990s there was an increase of $72 \%$ in the uptake 
of media studies at GCSE. This fact has been mirrored by a similar increase at AS/A2 level (advanced and intermediate level) and in higher and tertiary education.

\section{Malta}

In Malta, media education was formally introduced in schools in October 1981 (Borg and Lauri 2006). Books were purposely written and regularly updated to reflect changes in the media environment. The Ministry of Education also commissioned a study on media education and how it could be taught across the curriculum as had been recommended by Masterman, who was the main adviser on the subject for the Council of Europe (Vella 2008).

During the same period in a number of government and private schools media education was taught by some individual teachers who had received training in this subject. In December 1999, the Ministry of Education approved the new National Minimum Curriculum, 'Creating the Future Together'. This made it compulsory for all schools in Malta to teach media education. Objective 8, one of the 14 objectives of the curriculum, is dedicated to the teaching of media education. Each objective is subdivided into three sections: knowledge, skills and attitudes that students are expected to acquire by the end of their schooling. The following themes are included in this objective: media language; media and society; media content and media organisations.

The strategy adopted in government and private schools since 2000 was that media education should be taught as part of other subjects. Very limited components of media education - generally concerning aspects of content - were introduced in social studies, personal and social development at the primary and secondary levels and religion (Ministry of Education, Youth and Employment 2005; Department of Curriculum Management 2006; Deguara 2003). More importance to aspects of media education is given in ICT courses that are an integral part of the curriculum of the primary schools and secondary schools (Department of Curriculum Management 2006).

Church schools followed the option of teaching media education as a specialist subject. In 2008, the number of church schools which taught media education as a specialist subject at both primary and secondary level was 27 schools, 13 at primary level and 14 at secondary level (personal communication, October 2008). However the programme encourages the integration of particular topics in media education with other subject areas in the curriculum. Integration with other studies is easier to do at the primary level where children are taught most of the time by one teacher. At the secondary level, where students are taught by different teachers, integrating media education with other subjects is possible but more difficult.

\section{Germany}

In Germany, media education discourse started in the 1960s but was not established on the school curricula throughout the country before the beginning of the 1990s. As school policy in Germany is a federal responsibility, curricula and regulations differ slightly among the 16 federal states (Bundeslaender). Therefore there is no national curriculum but each state has its own curriculum. Some nationwide agreements between the 16 federal states guarantee basic general standards. However, many differences exist between school curricula of the federal states. 
Since the 1990s media education has in some way or other been part of the school curricula of every federal state. Although school authorities and teachers in Germany are more and more aware of its importance, media education generally is not a specialist subject in German schools. With the exception of the state of Thueringen, the curricula of the federal states make media education compulsory only as an integrated part of a variety of regular school subjects such as German, foreign languages, mathematics, art, music and social sciences. Regulations and plans (Rahmenplaene) for example the 'Media development plan for schools (Medienentwicklungsplan)' in the federal state of Baden-Wuerttemberg, or the 'Standards for media education' in the federal state of Rheinland Pfalz - define objectives and skills to be achieved starting from primary school level. Among these there are ICT skills, capacity of gathering information and doing research via media, media language, media analysis, reflection of media impact, communication, presentation, visualisation and media design (Landesmedienzentrum Baden-Württemberg 2004; Landesmedienzentrum Rheinland-Pfalz 2007).

A closer look at what is expected to be taught in the context of different school subjects shows that media education in many cases is reduced to ICT skills and skills to use the computer and specialised software for purposes like computer-based learning, text processing, dictionaries (languages), picture editing (art), spreadsheet and geometry programs (mathematics) (Ministerium für Kultus, Jugend und Sport Baden-Wuerttemberg 2004, S. 12).

Apart from the compulsory teaching of ICT skills (powerpoint, text processing, basics of spreadsheet) in Year 5 or 6 (ages 10-12) as part of mathematics and German language lessons, media education in Germany does not yet seem to play an important role in every day teaching. The extent to which media education is a topic in different subjects often depends on the involvement of individual teachers. Some reasons to explain the resistance could be that teachers often do not feel prepared enough, that the timetables of different school subjects are overloaded with important content other than media education, and that schools are not well enough equipped to provide technical support and facilities which can be used easily.

As already mentioned the federal state of Thueringen is the only one out of 16 to have introduced media education as a compulsory separate subject on the timetable for Class 5-7 (ages 10-13), where it is taught one hour a week. The curriculum defines three major objectives: students should acquire media competency, knowledge and skills to: (i) analyse and evaluate; (ii) to use; and (iii) to produce different media, i.e., printed media, audiovisual media and computers/the internet. The annual school reports students receive at the end of the school year contain a certificate ('Medienpass') to document in detail what has been learned and produced. In Class 810 (ages 14-15) the federal state of Thueringen provides computer science again as a compulsory seperate school subject to be taught up to three hours a week. In Class 11-12 (ages 16-18), at post-secondary level, computer science becomes an optional subject (Thüringer Kultusministerium 2004).

Optional subjects are also offered in schools of other federal states. In this context, ICT courses are widespread. However there are some other examples. For example in grammar schools (Gymnasien) in the federal state of Sachsen-Anhalt, an optional subject 'Modern media worlds' (Moderne Lebenswelten) can be chosen in Class 9 (see http://www.lisa-halle.de). In the federal state of Mecklenburg-Vorpommern some schools can develop a special profile to integrate media into teaching and learning and 
subsequently can be recognised as a 'multimedia school', while in the federal state of Nordrhein-Westphalen some schools have developed projects on how to use different media in the classroom.

\section{Teacher training in media education}

\section{England}

Initial teacher training courses are becoming increasingly popular in the UK, however very few courses provide teacher training in media education. The University and College Admission Service (UCAS) and the Graduate Teacher Training Registry (GTTR) websites reveal few initial teacher training courses that include the mention of media in their title. Three such examples are PGCE courses in English and media offered by Exeter University, London Metropolitan University and the University of Leicester, and one undergraduate course offered by the University of Stirling in English, film, media and professional education. Even though other training courses may contain some training in media education throughout their programme, this does not appear to be accredited.

\section{Malta}

In Malta, teacher training is also the weakest link in the media education initiative. There is no systematic formal and obligatory teaching in media education during teacher training at the University of Malta, which is the institution that trains students to become teachers. There is only one course ( 28 hours) directly on media education and this is available to those specialising in primary education. There is also a number of credits in ICT. This is an indication that training in teaching media education is maybe not given so much importance in this four-year course. Ad hoc short training courses are also organised by the Ministry of Education and by the Church's Media Centre. Such courses are not always patronised well by teachers, so much so that sometimes planned courses were either not organised or had to be cancelled due to lack of response. This happened in 2002, 2005, 2006, 2008 and 2009 (personal communication, 2009).

Since the majority of teachers in Malta have not been given any formal training in media education (Vella 2008), many find it difficult to teach the subject and as a result media education is sometimes not being taught as is required by the National Minimum Curriculum (Borg and Lauri 2009; Vella 2008). Some school administrators also complain that it is very difficult to find teachers who can teach media education. One reason for this is that media education is not being offered as an option in the Postgraduate Course in Education (PGCE courses) offered by the Faculty of Education in other different subjects.

\section{Germany}

In Germany the provision of training in media education during teacher training at the university is also very limited and again differs slightly between the federal states. In general, teacher training in Germany is divided into two phases; the first one has got its emphasis more on academic content (between three and four years depending on 
the academic grade to be achieved), the second one on practical experience of teaching (one-year long). During both phases some courses provide training in the use of different media for teaching such as software on different topics: the internet, audio, video or digital photography. Furthermore there are some courses focusing on media education in a broader sense, tackling for example media theories, communication research or different approaches of media education in theory and practice. The latter, in almost all cases, are not compulsory and there is no systematic training in media education provided for student teachers. There are, however, initiatives from universities and teachers in several federal states to change the curriculum in order to introduce media education as a compulsory basic module into the academic studies for student teachers. One example of a document that is claiming that media education is an important element in education is 'Keine Bildung ohne Medien! Medienpädagogisches Manifest' 2009. In addition it is being suggested that media education may also become a prerequisite to follow further training in teacher education.

Advanced training covering different aspects of media is regularly offered for teachers of all different types of schools by school authorities (Graduate Teacher Training: Lehrerfortbildung) and Media Training centres such as the Bildungszentrum BürgerMedien, a centre in Ludwigshafen supported by three federal states. While school authorities often concentrate on technical aspects and offer training such as how to set up and maintain computers in schools, media training centres regularly provide training covering different aspects of media education including how to use media for video or radio productions to be realised in classrooms. However, the number of teachers who attend such training is quite limited. Three recently conducted German studies show findings which could help to understand this situation:

- The comparatively low number of days in which German teachers take part in advanced training: nine days in Germany, 15 days is the international average (Institut für sozialwissenschaftliche Studien e.V. 2009).

- A sceptical attitude towards media training of those teachers who have little or no experience with the handling of digital media (Haeuptle et al. 2008).

- The increasing working load (more than 51 hours weekly when full time employed) German teachers face (Bauer et al. 2007). As findings by Esslinger (2002) and Hildebrandt (2008) show, almost all teachers who took part in their respective research studies claimed lack of time as one major obstacle to get involved into innovative subjects or school development processes. This situation explains why teachers' associations ask for advanced training to be implemented into the regular teaching load (see Hildebrandt 2008).

\section{Teachers' attitudes towards media education}

Due to the ambiguity of the position of media studies in the National Curriculum of several countries, the study of teachers' attitudes to teaching the subject has been the focus of several studies since the 1970s. In their study on the teaching of media in secondary schools, Murdock and Phelps (1973) found that $80 \%$ of grammar school teachers and $42 \%$ of teachers from comprehensives felt that the study of the mass media had little or no legitimate claim to classroom attention. It was still early days for media education and teachers who were probably not trained to teach the subject found it irrelevant. 
Two decades later the picture had changed dramatically. In his study Dickson (1994) found that $69 \%$ of teachers interviewed thought that media was "very important' and $87 \%$ taught media through another subject. Four years later Barratt (1998) found that $91 \%$ of a group of English teachers agreed that media studies was worthy of a place in the English curriculum. Therefore, not surprisingly, he also found that $90 \%$ of English departments include media education in their overall policy document. Although he found this growing enthusiasm for media work, Barratt also noted that:

- There was a disquiet amongst teachers about the coherence and rationale of NC requirements for media within English.

- Many teachers lacked confidence in assessing media.

- Most felt restricted by time constraints.

- Teachers felt in need of further training and proper resources.

Therefore even though media has become more popular among both teachers and students, training in the teaching of the subject has been largely inadequate. Indeed Hart and Hicks (2002) found that over $72 \%$ of their respondents could recall no formal in-service training for media education in recent years. The research reported in this paper, although a preliminary study, seems to confirm that this trend is still very much the same in the three countries.

\section{Methodology}

This study had three goals. One goal was to compare the different ways media education is integrated into the educational system of primary and secondary schools in three very different countries with the same European objectives for promoting and achieving media literacy for all students. Another goal was to find out the type of training in media education teachers are offered in their initial teacher training while the third and major goal was to find out the attitudes of teachers regarding media education. The interaction between variables such as training, experience, and the way media education is taught as well as the relationship these factors could have on the attitudes of teachers were also investigated.

Interviewing teachers from schools in different parts of a country present many difficulties related to financial and human resources. It was therefore decided that for this first comparative study an online survey would be used. The survey was translated and back-translated into the three languages. It was then posted on a dedicated website. In order for the questionnaire to reach as wide an audience as possible, central school authorities were asked to inform teachers about this online survey and give them the website address. This made it possible for teachers from different parts of the countries to answer the questionnaire. Using an online survey to collect data has both advantages and shortcomings. One of the major advantages is that the financial and human resources required to collect the data are minimal. On the other hand one major shortcoming is that the respondents are a volunteer sample and the results, like those obtained from all non-experimental designs, cannot be generalised to the population of Maltese, English and German teachers. All teachers were invited to answer the questionnaire, both those who actually teach media education as well as those who do not. This was done with the aim of comparing the attitudes of these two groups of teachers and find out whether there are any differences in their attitudes. 
The sample of teachers who answered the questionnaire came from different geographical areas of the three countries. With the exception of nine participants, the respondents were in favour that schools should teach media education and the majority $(88 \%)$ taught at primary and secondary levels in schools where media education is part of the curriculum. About half of the respondents $(47 \%)$ taught media education.

The questions asked were designed to find out what type of training teachers received in the teaching of media education. Other questions asked how important teachers rated media education, how prepared teachers felt after their teacher training to teach media education, and demographic variables such as the type of school they taught in and the year they finished their teacher training.

\section{Results}

\section{(1) Demographics}

The results being presented in this paper are those of a preliminary study of a sample of 132 participants, 33 teachers from the England, 52 teachers from Malta and 47 from Germany. Of the total sample, 43 respondents taught at primary level, 72 taught at secondary level, eight respondents taught at post-secondary level and another eight taught in other types of institutions. As many as 123 of the respondents in the sample taught in state schools. The type of initial teacher training received by these teachers was not the same for everyone. Many of the Maltese and German participants (25 Maltese and 29 German in all) and the majority of English participants (22 in all) had followed a Post-Graduate Certificate in Education. Some participants had followed other courses. Although media education should be taught in all schools in England, Malta and Germany, 70 respondents said that they do not teach media education at all. While 10 participants teach media education as a specialist subject, 49 participants teach media across the curriculum. Some teachers acquired their knowledge of media education through personal reading and interest. Only 50 respondents received training to teaching media education. Again this is a surprising finding since according to the Maltese and English National Minimum Curriculum as well as almost all of the German federal curricula, teachers should teach media education across the curriculum, implying that all teachers should have been trained in teaching media education.

\section{(2) Preparedness to teach media education}

Respondents were asked to rate on a scale from ' 1 ' to ' 5 ' how prepared they felt in teaching different aspects of media education after finishing their teacher training (' 1 ' = not prepared at all, ' 5 ' = very well prepared). The means are rather low and should give rise to concern to all those who are in charge of training our past and future teachers. Some of the respondents who said that they had not received training in media education did not answer this question. It is probable that since these teachers had not received any training at all, they taught that this question asking about how prepared they felt to teach media education did not apply in their case.

Table 2 indicates that teachers feel they are more prepared to teach about the content aspects (reading the media) than about the production aspects. Moreover when it comes to the production aspect (writing with the media), teachers feel more prepared to teach about the more traditional print media (e.g., newspaper production) and least prepared on the new media (e.g., designing a website). 
Table 1. A profile of the teachers who answered the questionnaire.

\begin{tabular}{|c|c|c|c|}
\hline & $\begin{array}{l}\text { English } \\
\text { teachers }\end{array}$ & $\begin{array}{l}\text { Maltese } \\
\text { teachers }\end{array}$ & $\begin{array}{l}\text { German } \\
\text { teachers }\end{array}$ \\
\hline Sample number & $\begin{array}{c}33 \\
\text { Male }=11 \\
\text { Female = 22 }\end{array}$ & $\begin{array}{c}52 \\
\text { Male }=18 \\
\text { Female = } 34\end{array}$ & $\begin{array}{c}47 \\
\text { Male }=25 \\
\text { Female }=22\end{array}$ \\
\hline Taught in state schools & $30(91 \%)$ & $49(94 \%)$ & $44(94 \%)$ \\
\hline Received training in media education & $13(39 \%)$ & $11(21 \%)$ & $26(55 \%)$ \\
\hline Taught media education & $19(58 \%)$ & $16(31 \%)$ & $27(57 \%)$ \\
\hline $\begin{array}{l}\text { Believed that media education should } \\
\text { be taught in schools }\end{array}$ & $29(88 \%)$ & $48(92 \%)$ & $46(98 \%)$ \\
\hline
\end{tabular}

A one-way ANOVA to assess the differences across the three samples from the different countries gave significant differences for newspaper production $(\mathrm{F}=3.95$, $p=0.02)$, advertising $(F=5.31, p=0.01)$, genres $(F=3.30, p=0.04)$ and media influence $(F=3.27, p=0.04)$. One reason for the fact that the English teachers scored higher on advertising and programme genres could be that these topics are covered as part of the English/literature curriculum. In the case of newspaper production a reason why the German teachers scored significantly higher in this area could be related to the fact that in many German cities there is a long-term cooperation between local newspaper organisations and schools. Students are invited to take part in 'newspaper production'. They get the opportunity to write articles and get them published on a specialised school page of the respective local newspaper.

There were significant differences in how prepared the sample of teachers who teach media education felt in teaching the various topics mentioned in Table 2 as opposed to the sample who did not teach media education. The first sample felt more prepared to teach about stereotyping $(\mathrm{t}=2.4 ; \mathrm{df}=96 ; \mathrm{p}=0.02)$, media in society $(\mathrm{t}=3.4 ; \mathrm{df}=99, \mathrm{p}=0.01)$, news $(\mathrm{t}=2.4 ; \mathrm{df}=98 ; \mathrm{p}=0.03)$, media influence $(\mathrm{t}=3.0$; $\mathrm{df}=98 ; \mathrm{p}=0.01)$, advertising $(\mathrm{t}=2.4 ; \mathrm{df}=97 ; \mathrm{p}=0.02)$ and media content $(\mathrm{t}=2.8$; $\mathrm{df}=99 ; \mathrm{p}=0.01)$. There were no significant differences for other topics, that is, for teaching about television, radio and newspaper production, designing a website, ownership and bias in the media and programme genres. It seems that all teachers felt unprepared to teach these topics, possibly because even those who had received training in teaching media education had not received so much preparation in these topics.

\section{(3) Perceived importance of media education}

When asked to rate the importance of 10 subjects including media education on a scale from ' 1 ' to ' 10 ' (' 1 ' = least important, ' 10 ' = most important), media education was placed in the sixth place when the ratings of all participants from the three countries were considered. When analysed by nationality, English teachers rated it in eighth place, Maltese teachers in the seventh place while German teachers in the fifth place. The teaching of English language and mathematics received the highest ratings by the teachers from the three countries (see Table 3). When the perceptions of the sample of teachers who taught media education was compared to those who did not teach media education regarding the importance of the various subjects shown in Table 3, no significant differences were found except for the teaching of personal and social 


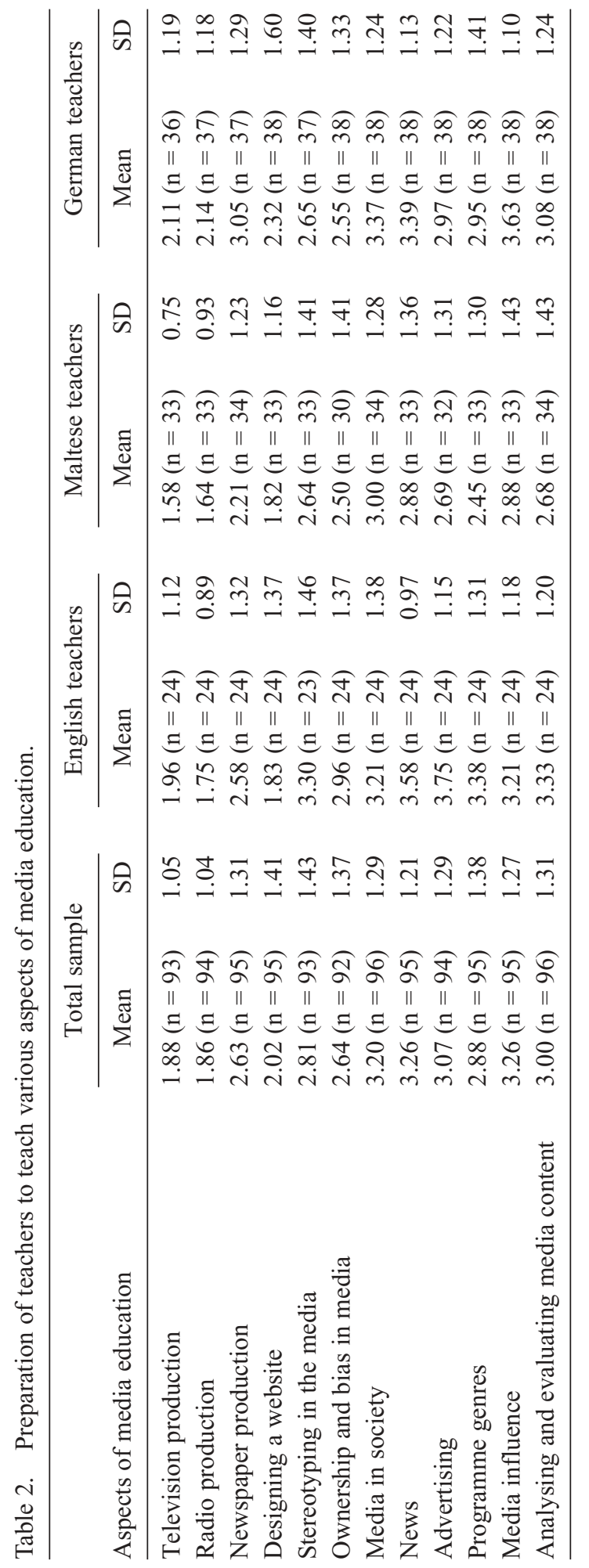




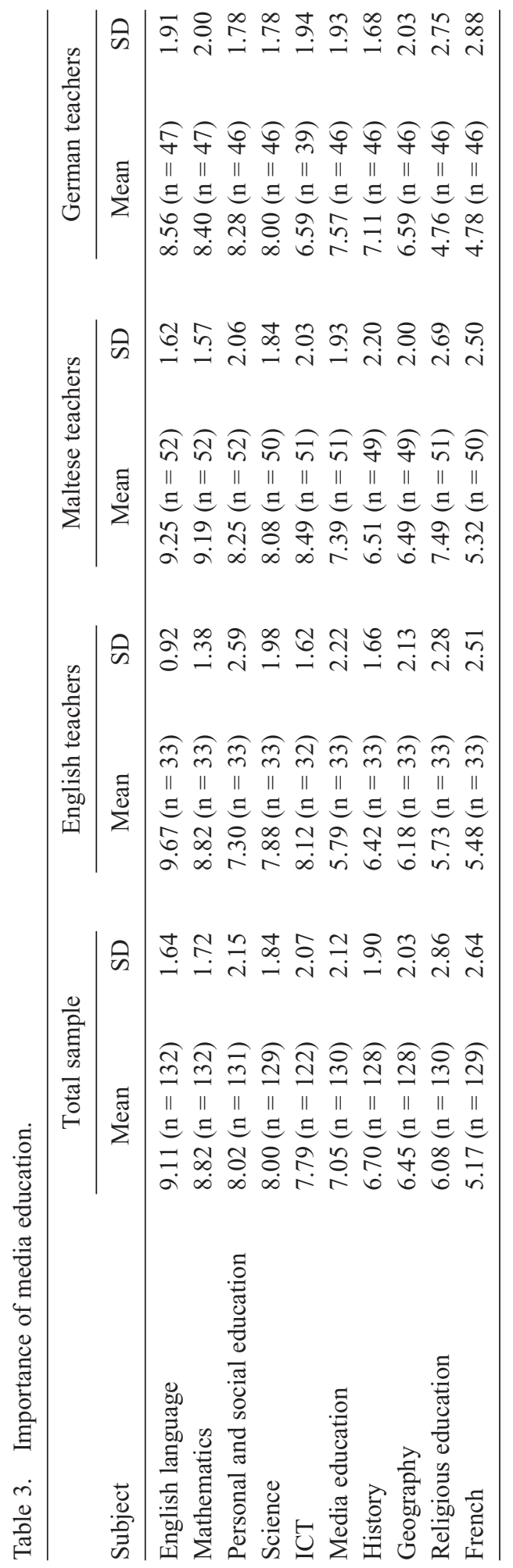


education (PSE). This subject was considered less important by those teachers who taught media education. Possibly teachers who did not teach media education considered PSE as more important because media education can be taught through PSE. This is in fact the practice in some schools.

\section{(4) Teaching media education as an interdisciplinary subject}

Participants who taught media education as an interdisciplinary subject were asked to list the subjects through which they teach media education and the topics they discuss. It is relatively clear that only a limited number of topics are discussed and this confirms the arguments put forward by Minkkinen (1978) and Frau-Meigs (2006), who pointed out that teaching media education as an interdisciplinary subject can mean that not all aspects of media education are covered.

A one-way ANOVA to assess the differences across the three samples from the different countries gave significant differences for English $(F=4.85, p=0.01)$, media education $(\mathrm{F}=8.79, \mathrm{p}<0.01)$, religion $(\mathrm{F}=13.55, \mathrm{p}<0.001)$ and ICT $(\mathrm{F}=11.68$, $\mathrm{p}<0.01)$. It is to be expected that English and Maltese teachers would rate English significantly higher than their German counterparts since English is the official language in both countries (together with Maltese in the case of Malta). Moreover, the high rating given to religion by Maltese teachers can be explained by the fact that more than $98 \%$ of the population were baptised in the Roman Catholic Church (The World Factbook 2008) and around 53\% attended mass on Sunday (Discern, Sunday Mass Attendance Census 2005, Preliminary Report, August 2006). Religion is also a compulsory subject in the curriculum. Perhaps it is more difficult to explain the significant differences in the ratings given by the three groups of teachers to media education and ICT. English teachers rated media education significantly lower than the other two groups of teachers whereas the German teachers rated ICT much lower than the English and Maltese teachers. Some teachers involved in media education in Germany tend to be critical towards those approaches to media education which particularly highlight ICT, giving it more importance than other areas. These approaches are often regarded as being too limited, as stated among others by Martina Schmerr (2001), speaking for the trade union for teachers (Gewerkschaft Erziehung und Wissenschaft, GEW). Many teachers seem to prefer more holistic approaches which include a variety of additional competencies such as communication competence, media competence, and self-responsibility. The 'Ludwigsburger Erklaerung: Medien in der Lehrerbildung' (Ludwigsburg statement on media education as part of teacher training) issued in December 2008 and supported by a remarkable number of schoolteachers, university teachers and professors, gives detailed evidence of these demands.

Table 4 shows that there is a focus on media content and in some the topics seem to point to a defensive approach to media education. There are references to 'subtle influence' and 'morally negative messages' but no reference to the positive element on the media. Two important areas which are missing are media languages and the relation of media and society. The element of 'writing' with the media or media production, which many consider as an integral part of a media education programme, is also lacking. The only reference is to 'creative writing' and 'creating a class magazine'. The bias is thus in favour of the print media which are not the media most used by children. 
Table 4. Subjects through which media education is taught.

\begin{tabular}{ll}
\hline Subject & Topic \\
\hline $\begin{array}{l}\text { History } \\
\text { Religious education }\end{array}$ & $\begin{array}{l}\text { Liberty of press } \\
\text { Choosing the right programmes; being aware of the subtle } \\
\text { influence of the media; avoiding and discussing morally } \\
\text { negative messages } \\
\text { How to use the media to learn; discuss different means of } \\
\text { communication; advertising; slogans and captions }\end{array}$ \\
Maltese/English/German & $\begin{array}{l}\text { Creative writing; language } \\
\text { English/German }\end{array}$ \\
& $\begin{array}{c}\text { Creating a class magazine; propaganda; newspapers; } \\
\text { advertising; bias; newspaper lead stories; editorial }\end{array}$ \\
Drama & writing; persuasive techniques \\
Art & Film and television drama \\
PSD & Animation \\
\hline
\end{tabular}

\section{(5) Objectives of teaching media education}

The protectionist approach to media education is also confirmed by the results in Table 5 .

A one-way ANOVA to assess the differences across the three samples from the different countries gave significant differences for protection of students from antisocial messages $(\mathrm{F}=5.69, \mathrm{p}<0.01)$, avoiding morally negative media messages $(\mathrm{F}=$ $6.05, \mathrm{p}<0.01)$ and familiarising and appreciating aesthetically beautiful media messages $(F=3.61, p<0.03)$. The Maltese sample rated significantly higher in importance both the objective of protection of students and also of appreciating aesthetically beautiful messages. In Malta children are still very protected. Children and many adolescents and young adults live with their parents until they are well into their $20 \mathrm{~s}$. It is to be expected that within this type of sheltered society some teachers consider the protection of students from morally negative media messages as an important objective of media education. This protectionist attitude is counterbalanced by the importance given to the aesthetic dimension which is reflected in the thrust of the media education programme. German teachers rated significantly lower the importance of helping students avoid morally negative messages of the media. This could be the result that German teachers may have identified this item with normative media pedagogy, an approach based on a sceptical view of media which aims to 'protect' young people from negative messages of the media. Many German teachers criticise this approach, preferring the action-oriented media (AOMP) approach discussed above. In this approach students, while creating and realising their own media productions, analyse and critically review media constructions, judging to what extent media represent certain interests and interest groups. In the process, students are prepared to deal with and avoid morally negative messages of the media without being explicitly 'protected'.

\section{(6) Specialist subject versus interdisciplinary subject}

The participants were also asked their opinion regarding how media education should be taught, that is, whether media education should be taught as a specialist subject or across the curriculum. Some participants did not answer this question (see Table 6). 


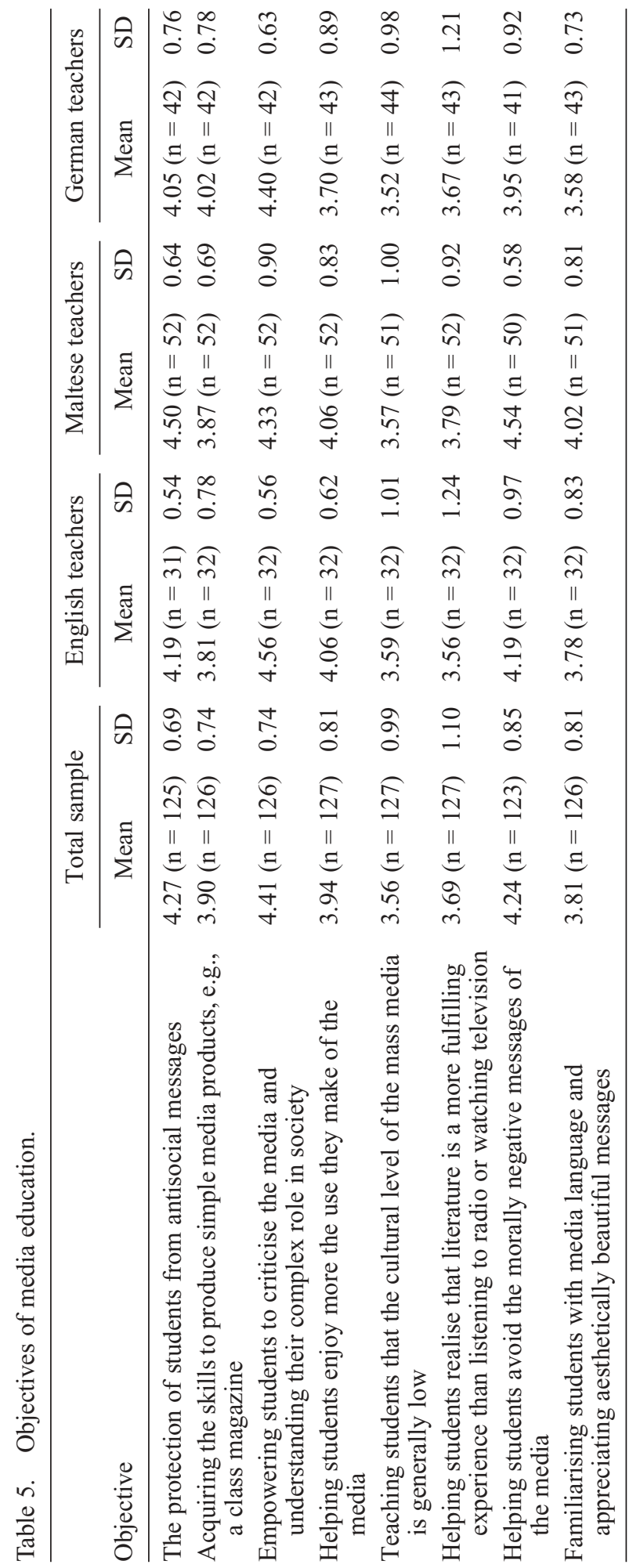


Table 6. Best method of teaching media education to students.

\begin{tabular}{lccc}
\hline Method & English teachers & Maltese teachers & German teachers \\
\hline Specialist subject & 7 & 11 & 6 \\
Across the curriculum & 7 & 24 & 24 \\
Both as a specialist subject & 15 & 12 & 15 \\
$\quad$ and across the curriculum & 1 & 2 & 1 \\
Other & & & \\
\hline
\end{tabular}

There were no significant associations found when the answer to whether schools should teach media education was cross-tabulated with the year respondents finished their teacher training (chi-squared $=2.74, \mathrm{p}=0.25, \mathrm{df}=2$ ). It was expected that those who finished their training after the year 2000 would be more in favour of teaching media education in schools since media education became part of the National Minimum Curriculum. Neither was there a significant difference in teachers' attitudes towards teaching media education when the type of teacher training was taken into consideration, that is, whether they had read for an undergraduate degree in teacher training or whether they followed a post-graduate course in education (chi-square $=$ $2.32, \mathrm{p}=0.68, \mathrm{df}=4)$.

\section{Conclusion}

The increasing presence of different media in the life of children and adolescents, as well as its great influence even from the preschool age, is well documented (Thorn 2008). Ofcom, the independent regulator authority for the communications industries in the United Kingdom has argued that since the world around us is changing rapidly with the various media and communication technologies becoming an integral part of everyday life, knowledge of their use is increasingly becoming a prerequisite to effective participation in society and in the economy (Ofcom 2008). Ofcom's position is supported by several national and international policy documents some of which were referred to above.

In spite of these recommendations the present status of media education three decades after its introduction is not as strong as it should be as can be seen from this study. Awareness of the influence of the media and the belief that audiences should be given the skills to become more cognisant of this influence has been promoted in policy documents about media education. These recommendations have not been adequately reflected in the school curricula and as the results of this preliminary study shows, teachers who should be teaching media education as an interdisciplinary subject are in fact not doing so. Those responsible for the education and the development of children may not be sufficiently aware of the need for media education and consequently may not be too willing to tackle the problems which are hindering media education from appearing on the students' timetables. The influence of the media in the lives of children and adolescents needs to be appropriately addressed by educators and policy-makers.

In this preliminary study, analysis of participants' confidence in teaching a range of aspects of media revealed a general lack of confidence. Television production, radio production, and website design were the areas that Maltese, English and German 
participants felt least confident teaching. It seems that the sample of teachers from the three countries do not seem to be familiar with production and action oriented media pedagogy, a fact that could be changed if media education in all its dimensions becomes a compulsory component of both of the curriculum for student teachers as well as advanced training for teachers.

The study also highlighted the little time devoted to media education in initial teacher training courses as well as in schools. This inconsistency is true both across and within English, German and Maltese samples. The findings of the current study should provide impetus for further research. Policy-makers and educationalists should perhaps evaluate the importance being giving to media education and make the necessary changes to the programmes they offer both at initial teacher training courses and post graduate courses. Any student not equipped with the tool of media analysis and media use is at a disadvantage in a media saturated culture.

\section{Acknowledgements}

The authors would like to thank Anja Bechstein who helped us to contact important institutions in Germany and translate and spread the questionnaire. We would also like to thank the referees for their careful reading of the paper and their comments.

\section{Notes on contributors}

Mary Anne Lauri lectures in social psychology at the Department of Psychology, University of Malta. She is a Chartered Member of the British Psychological Society. Her areas of research are the study of social representations applied to social issues including religion, social marketing health and the media. She is a member of the Editorial Board of the Public Broadcasting Services in Malta.

Joseph Borg lectures in communication studies at the University of Malta. He was responsible for the introduction of media education in church schools in Malta, co-authored the media books used in secondary schools and is the author of several papers on media education. Borg is the audio-visual policy consultant for the Minister for Education and Culture.

Traudel Günnel holds a $\mathrm{PhD}$ in media education and is a member of the academic staff of the Paedagogische Hochschule Freiberg (University of Education, Germany). She has been involved in community media and media education since 1979. She is and has been a leading partner of several international research projects including 'Digital Dialogues', 'Media Training Across Europe', and currently 'CROSSTALK: Moving stories from across borders, cultures, generations', all supported by the European Union.

Roberta Gillum has a BA (Hons) in linguistics and a PGCE (Secondary) in English from the University of Leicester. She currently teaches at King Edward VI College in Nuneaton in the post of ESOL coordinator.

\section{References}

Audiovisual Media Services Directive. 2007. Official Journal of the European Union 332: 27-45.

Baacke, D. 1997. Medienpädagogik. Tübingen: Max Niemeyer Verlag.

Barratt, A.J. 1998. Audit of media in English. London: BFI.

Bauer, J. et al. 2007. Working conditions, adverse events and mental health problems in a sample of 949 German teachers. International Archives of Occupational and Environmental Health 80: 442-229. 
Borg, J., and M.A. Lauri. 2006. An evaluation of media education in Malta. IAMCR Cairo. $25^{\text {th }}$ Conference and General Assembly. Proceedings, 341-46.

Borg, J., and M.A. Lauri. 2009. Empowering children in a changing media environment: Media education in the Maltese educational system. In Issues in information and media literacy: Criticism, history and policy, ed. M. Leaning, 113-36. California: Information Science Press.

Bowker, J. 1991. Secondary media education: A curriculum statement. London: BFI.

Buckingham, D. 1993. Changing literacies: Media education and modern culture. London: Institute of Education.

Buckingham, D. 1998. Media education in the UK: Moving beyond protectionism. Journal of Communication 48, no. 1: 33-43.

Buckingham, D. 2003. Media education. Literacy learning and contemporary culture. Cambridge: Polity.

Deguara, G. 2003. Il-Progett ta' Alla f'hajti. Malta: Kummissjoni Kateketika Nazzjonali.

Department for Curriculum Management. 2006. Syllabus for primary schools. Malta: Ministry for Education, Youth and Employment.

Dickson, P. 1994. A survey of media education in schools and colleges. London: BFI.

Discern. 2006. Sunday Mass Attendance Census 2005. Preliminary Report. August 2006.

Enzensberger, H.M. 1970. Baukasten zu einer Theorie der Medien. In Kursbuch 20, ed. H.M. Enzensberger et al. Berlin: Rowohlt.

Esslinger, I. 2002. Berufsverständnis und Schulentwicklung: ein Passungsverhältnis? Bad Heilbrunn: Klinkhardt.

Frau-Meigs, D. 2006. Media education - A kit for teachers, students, parents and professionals. http://unesdoc.unesco.org.

Gerbner, G. 1981. Die 'anstrengende' Welt des Vielsehers. In Der Vielseher: Herausforderung für die Fernsehforschung und Gesellschaft, ed. H. Oeller. München: Saur.

Glogauer, W. 1991. Kriminalisierung von Kindern und Jugendlichen durch Medien. BadenBaden: Nomos.

Günnel, T. 2001. Rundfunklandschaft im strukturellem Wandel. In Handlungsorientierte Medienpädagogik im Bürgerradio, ed. J. Fichtner, T. Günnel, and S. Weber. München: kopaed.

Günnel, T. 2006. Action-oriented media pedagogy: Theory and practice. In From the margins to the cutting edge. Community media and empowerment, ed. P. Lewis and S. Jones. Cresscil, NJ: Hampton Press.

Haeuptle, E., A. Florian, and G. Reinmann. 2008. Nachhaltigkeit von Medienprojekten in der Lehrerfortbildung (Arbeitsbericht No. 20). Augsburg: Universitaet Augsburg.

Hall, S., and P. Whannel. 1964. The popular arts. London: Hutchinson.

Harris, R.J. 2004. A cognitive psychology of mass communication. London: Lawrence Erlbaum Associates.

Hart, A., and A. Hicks. 2002. Teaching media in the English curriculum. London: Trentham Books.

Hildebrandt, E. 2008. Lehrerfortbildung im Beruf. Eine Studie zur Personalentwicklung. Weinheim: Juventa.

Hüther, J. 2004. Pioniere und Wegbereiter der Medienpädagogik. Merz, Medien und Erziehung: Zeitschrift für Medienpädagogik 48, no. 1: 52-7.

Hüther J., B. Schorb, and C. Brehm-Klotz. 1997. Grundbegriffe Medienpädagogik. München: kopaed

Institut fuer sozialwissenschaftliche Studien (ISS) e.V. 2009. Erste Ergebnisse von TALIS GEW Deutschland (Lueneburg) http://www.gew.de/Binaries/Binary50253/3_GEW_ First_Results_deck.pdf.

Jankowski, N. 2002. The conceptual contours of community media. In Community media in the information age, ed. N. Jankowski, with O. Prehm, 3-16. Creskill, NJ: Hampton Press.

Keine Bildung ohne Medien! Medienpädagogisches Manifest. 2009. http://www.ph-ludwigsburg.de/fileadmin/subsites/1b-mpxx-t-01/user_files/Medienpaedagogisches_Manifest_ 2009.pdf.

Kleinsteuber, H. 1991. Radio - das unterschaetzte Medium. Berlin: Vistas. 
Landesmedienzentrum Baden-Württemberg. 2004. Materialien für die Medienentwicklungsplanung. Stuttgart: Eigenverlag.

Landesmedienzentrum Rheinland-Pfalz. 2007. Medienkompetenz macht Schule. Medienbildung in der Primar- und Sekundarstufe I. Bausteine für eine veränderte Lehr- und Lernkultur. Koblenz: Eigenverlag.

Leavis, F.R., and D. Thompson. 1933. Culture and environment: The training of critical awareness. London: Chatto \& Windus.

Ludwigsburger Erklärung Dezember. 2008. http://www.ph-ludwigsburg.de/fileadmin/ subsites/1b-mpxx-t-01/user_files/Ludwigsburger-Erklaerung.pdf.

Masterman, L. 1985. Teaching the media. London: Comedia Publishing Group.

Masterman, L. 1988. The development of media education in Europe in the 1980s. Strasbourg: Council of Europe.

Ministerium für Kultus, Jugend und Sport Baden-Wuerttemberg. 2004. Medienentwicklungsplanung für die Schulen. Stuttgart: Vertrieb Landesmedienzentrum Karlsruhe.

Ministry of Education, Youth and Employment. 1999. Creating the future together. National minimum curriculum. Malta: Maltese Government.

Ministry of Education, Youth and Employment. 2005. PSD syllabus for seconday schools. Malta: Maltese Government.

Minkkinen, S. 1978. A general curricular model for mass media education. Spain: J.M. Llorca.

Murdock, G., and G. Phelps. 1973. Mass media and the secondary school. London: Macmillan.

Ofcom. 2008. Review of Ofcom's media literacy programme 2004-2008. 19 December 2008.

Parliamentary Assembly of the Council of Europe. 2000. http://assembly.coe.int/Documents/ AdoptedText/ta00/EREC1466.HTM.

Pfeiffer, C. et al. 2007. Die Pisa-Verlierer-Opfer ihres Medienkonsums. Eine Analyse auf der Basis verschiedener empirischer Untersuchungen. Hannover: Kriminologisches Forschungsinstitut Niedersachsen EV.

Schell, F. 1999. Aktive Medienarbeit mit Jugendlichen: Theorie und Praxis. München: kopaed.

Schmerr, M. 2001. Neue Medien. Ab ins Netz oder darfs noch etwas mehr sein? Neue Medien und Schule. www.abc-der-ganztagsschule.de/Neue_Medien.html.

Schorb, B. 1995. Medienalltag und Handeln. Opladen: Leske und Budrich.

Spitzer, M. 2005. Vorsicht Bildschirm! Elektronische Medien, Gehirnentwicklung, Gesundheit und Gesellschaft. Stuttgart: Klett.

The World Factbook. 2008. www.cia.gov/library/publications/the-world-factbook/geos/ mt.html.

Thorn, W. 2008. Preschool children and the media. Communication Trends 27, no. 2: 3-28.

Thüringer Kultusministerium. 2004. Verwaltungsvorschrift zur "Medienkompetenzentwicklung an den Thüringer allgemein bildenden Schulen. Gz:12/51130-0.

UNESCO. 1982. The Grunwald Declaration. www.unesco.org/education/pdf/MEDIA_E.PDF.

Van Evra, J. 1998. Television and child development. London: Lawrence Erlbaum Associates.

Vella, T. 2008. The challenges of media literacy and the Maltese educational system. Masters Dissertation, University of Malta.

Von Feiltzen, C., and U. Carlsson. 2004. Promote or protect. Perspectives on media literacy and media education regulations. Goteborg: Nordicom.

Williams, K. 2003. Understanding media theory. London: Arnold. 